\title{
Ensuring Success in School is About More Than Getting A's: Layered Stories
}

\author{
Corinne McKamey \\ Rhode Island College
}

\section{Author Note}

Corinne McKamey, Elementary Education, Rhode Island College, and CoDirector, Youth Development B.A., Rhode Island College. A version of this paper was presented at the Narrative Matters Conference in Paris, France in May 2012.

Correspondence concerning this article should be addressed to Corinne McKamey, Assistant Professor, Elementary Education, Rhode Island College, 600 Mount Pleasant Ave., Providence Rhode Island 0298. E-mail: cmckamey@ric.edu

\begin{abstract}
I begin this paper with a reader's theatre text that represents the multiple perspectives of a student, teacher, student teacher, and administrator about a high school class schedule change. In presenting a text that portrays multiple points of view upon what would seem to be an everyday experience in an urban high school, I aim to show the complexity of how different people in different roles respond and manage their context in response to a single policy decision. After the reader's theater and before I continue with the rest of the paper, I invite you the reader to consider your interpretations of and associations with the text. I conclude by arguing that we need to be attuned to the complex ways that policy decisions inform and constrain the actions of people within educational contexts.
\end{abstract}

Keywords: policy decisions; effects; urban schools; English language learners; layered stories; reader's theater 


\section{Ensuring Success in School is About More Than Getting A's: Layered Stories}

I begin this paper with a reader's theatre text that represents the multiple perspectives of a student, teacher, student teacher, and administrator about a high school class schedule change. I witnessed this event while I was a university supervisor and researcher in a public urban high school. This story begins with Ruby, a high school junior, sitting resolutely in the front of an overcrowded history classroom, refusing to leave the room as her schedule change dictated. Ruby loudly states, "This is my class! I came to my class! I went to the other room, and there is no teacher there...!" As I watched the incident above unfold, my heart ached for Ruby. I had seen this kind of scene played repeatedly in the years I had worked in urban schools where students' individual needs as learners became tangled and disrupted by an institutional rule or context. Ruby later asked me if I would find out more about why her schedule had changed. Over the next few days, I talked with the people involved: Mr. Hansen, the history teacher; Mr. Smith, the student teacher; and Mr. Medina, the school administrator. I was struck that each person's perspective fractured the initial incident into multiple meanings and negotiated situations. Moreover, each story was silently elicited by a state-level policy change about bilingual education.

I have chosen to use a reader's theater format to re/present different exchanges and observations that I had about Ruby's schedule change for a few reasons. First, the boxed structure of the genre reinforces the idea that each person's perspective, struggle, and ways of managing success in the school was presented to me in isolation from the others. Second, in presenting a text with "layered stories" that represent multiple points of view, I aim to show the "diverse ways through which experience is constructed" (Ely, 2005, p. 71) in response to a single policy decision. Finally, the reader's theater format, which is somewhat disjointed and fragmented, disrupts the idea that there is, or could be, a single coherent story about this event (Counternormativity Discourse Group, 2005).

After the reader's theatre and before I continue with the rest of the paper, which is written in more traditional academic prose, I will ask you to consider your interpretations of and associations with the text. This prompt, combined with the multiple voices re/presented, invites you the reader to experience and construct your own story in relation to this text (Donmeyer \& Yennie-Donmeyer, 1995; 1998). I conclude by raising questions about the importance of creating spaces within schools where people can speak, juxtapose, and layer different perspectives and experiences towards synergistically attending to policies and obstacles within urban schools.

\section{Schedule Change: A New History Class for Ruby}

\section{Perspectives:}

Corinne, university supervisor and doctoral researcher

Ruby, high school junior

Mr. Smith, student teacher

Mr. Hansen, history teacher 
Mr. Medina, school administrator

In the following scenes, speakers are talking to Corinne in response to variations of the question, "tell me about Ruby's schedule change."

Setting: In various locations within International Studies High School (ISHS), a public urban high school in Massachusetts. Of the 317 students in the "school within a school," almost half (47\%) were English Language Learners and most students were fluent in a language other than English. Partly because of a state policy change, six teachers at ISHS with bilingual expertise were fired over the summer, and the school opened the year understaffed.

\section{Perspective 1: In an overcrowded history classroom}

Corinne (researcher and university supervisor):

I stood at the back of Mr. Hansen's high school history classroom observing Mr. Smith, one of the student teachers I was supervising. I looked around the room and saw several students I knew among the 40 students sitting in desks, at tables, and standing up in the back of the room leaning against the windows because there were no more seats. I saw that Ruby (Nigeria) and Malik (Liberia) were sitting up in the front of the room. Mr. Smith walked over to Ruby, leaned over slightly, and said something to her. Ruby sat upright in her chair and I heard her say, "This is my class! I came to my class! I went to the other room, and there is no teacher there. Mr. Hansen is my teacher, I am here to learn!” Mr. Smith raised his hand, as if to make a point, as he said something quietly to her, and she said, very loudly, "Why does Mr. Hansen not like me? Why does he want me to leave his class?" She continued, "I'm not going over there [the other classroom] until there is a teacher. I come to school to learn!”

\section{Perspective 2: To Corinne in the hallway after school:}

Ruby (high school junior):

We are supposed to be in another class, but I went there, and there was no teacher, just 12 or 13 students. It was too crazy for me; we were just sitting there, people were talking, and just sitting there with no teacher; we weren’t learning anything, and so I went back to Mr. Hansen’s class. I like Mr. Hansen; I don’t know why he changed me out of the classroom.

\section{Perspective 3: In a post-observation debrief between Corinne and Mr. Smith:}

Mr. Smith (student teacher):

We had 40 students in the classroom, and we had to make a decision about which students we wanted to transfer to a new class. We chose to move students who were struggling to keep up with the class because of English language issues. It's hard enough 
to teach a class of 40 students, and even harder still to attend to students who are really struggling with English. Mr. Hansen doesn't have a lot of expertise teaching ELL students, and I am interested in learning how to teach ELL students, but I'm overwhelmed with a full class of students with regular needs. We thought that the ELL students would benefit from having a smaller class, and more attention from a teacher who knows more about teaching ELL students.

\section{Perspective 4: In a hallway conversation between Corinne and Mr. Hanson:}

Mr. Hansen (history teacher):

I filed a grievance with the union 2 weeks ago stating that my class was too large according to union rules. The school had 2 weeks to respond, and I worked with other teachers to find a workable solution. If I thought things would have changed, that my class size would have gotten smaller without the grievance, I would have waited. But I know nothing would have happened. Teachers are often not heard in the school; we state our concerns and issues, and administrators or the people at the district central office nod their heads and then nothing happens. Filing a grievance is one way to "be heard" by the principal. Even if you don't like the way he handles the problem, he hears your problem, and he has to respond to your problem.

\section{Perspective 5: In a conversation between Corinne and Mr. Medina in his office \\ Mr. Medina (administrator):}

Sigh. It's not an ideal situation. I don't have many options to place students. I found a classroom for the students whom we transferred from Mr. Hansen's class, but getting a teacher is much harder and takes time. I asked the principal, who asked central office, and they are now looking at a pool of teachers, and it just takes a lot of time. I requested a substitute teacher for the class, but subs either don't show up or they leave before the end of the school day. There are two other girls, Leticia and Amanda; we have talked about them before. They are sophomores and should be taking Algebra I, but I had to schedule them into Algebra II because I just didn't have space anywhere else. In that case, too, I'm waiting for permission to hire another math teacher, but in the meantime, at least the students are in some sort of math class. Sigh. The district cut too many teachers over the summer, and it's taking a lot of time to get teachers back into the building.

\section{Perspective 6: In your own mind as you the reader are reading and reflecting on this} text.

You (the reader):

- What strikes you about the above text?

- With which perspectives did you most relate?

- What does "success" mean in these stories? 
- Does reading this text cause you to think about experiences in your own professional or personal life?

\section{The Importance of Attending to School Experiences}

I begin this paper with layered stories from within a particular urban school context because, quite frequently, the stories and perspectives of people for whom educational policies and research are created are often not the dominant voices within peer reviewed educational journals. I agree with Craig (2010), who argues that "not nearly enough attention has been paid to school contexts - which are overwrought with mandates, imperatives, and best ways of doing things (frequently working in opposition with one another) - and how they bind and constrain what teachers are able to know and do" (p. 133). This analysis supports Craig's observation and expands its scope to include how contexts constrain not just teachers, but also administrators and students.

Because experiences unfold in "storied landscapes” (Clandindin, Murphy, Huber, \& Orr, 2010, p. 81), the narratives embedded in the reader's theater text are a particularly relevant way to relate and understand each person's perspective. By using the term "narrative," I draw from the tradition of experience-centered narrative research (Mishler, 1995; Squire, 2008; Tsai, 2007), which defines narrative representations as having a sequential, causal, or thematic order and which illustrate the teller's understanding of an experience. In the above reader's theater, there are several narratives told by individual people. I am telling a broader narrative through piecing together multiple narratives. Narrative researchers argue that stories capture the complexity of experience in ways that other methods cannot. Narrative analysis often analyzes multiple layers of meaning in stories, including how the teller positions him or herself, major themes, story genre, when and how the audience is acknowledged, and so on (Lyons, 2007). Stories can also reveal the storyteller's tacit understandings and beliefs that inform, and are informed by, culture (Quinn, 2005). In presenting and analyzing layered stories around a particular event, my aim is to capture the complexity of perspectives and orientations towards a particular situation.

\section{The Research Study and Policy Context}

The stories in this paper are drawn from my ethnographic dissertation study, which examined how immigrant students negotiated and developed communities of caring within the International Studies High School (ISHS) in an urban center in Massachusetts (McKamey, 2006; McKamey, 2011a; McKamey 2011b). ISHS was housed with several other small schools within a building that I will call "Washington High." ISHS specialized in serving immigrant students who were English Language Learners (ELL's). About 150 of the 317 students were ELL students. Students were of diverse origins, and came from many countries. Although the school did not keep official records on countries of origin, one group of students who conducted a survey of their peers told me that ISHS students had lived in over 70 different countries, including Albania, Argentina, Brazil Dominican Republic, Ethiopia, Ghana, Guatemala, India, Iran, Iraq, Liberia, Nepal, Pakistan, Puerto Rico, Russia, and Somalia. 
In the first year of the study, the school had extra support staff and teachers who taught specialized classes for English Language Learners using several transitional bilingual strategies. Some classes supported Spanish-speaking students, and were taught by bilingual teachers who used both Spanish and English to instruct. Other classes were taught by teachers who used a variety of instructional techniques, such as using more visual aids or focusing instructional time on English language vocabulary instruction. This situation changed when state voters passed, with a wide margin, an initiative to replace transitional bilingual programs with an immersion-based program.

The "English Only" state policy, like many others across the United States (Iddings, Combs, \& Moll, 2012; Cadiero-Kaplan \& Rodríguez, 2008, Karp \& Uriarte, 2010) aimed to assimilate English Language Learners quickly into English speaking classrooms in a seemingly democratic and efficient matter. The ideal language transition class, as framed by this policy, would generally not last more than a year. This policy also upheld a democratic ideal: Students who are from different native-language groups but who have similar levels of English skills would be placed together in classrooms and quickly mainstreamed into regular education classrooms (Karp \& Uriarte, 2010).

The policy had many repercussions as it unfolded in the public school system. As a result of this decision, Washington High fired six teachers who specialized in ELL instruction. These firings had consequences that were experienced differently by members of the school, including those who were involved in Ruby's history schedule change. I witnessed Ruby's scheduling incident and pursued knowing more about these stories in part because Ruby asked me to find out more information. I was also personally interested in hearing more about different perspectives on this situation because the constraining conditions of the school and resulting dilemmas for educators and students seemed strikingly familiar to me.

\section{Research Role}

During the 2 years that I collected data, I assumed multiple roles and responsibilities within the school, including supervising student teachers, chaperoning field trips, and observing and interviewing students and teachers for another education research project (Luttrell, Ward, \& Holland, 2006). Because I was in the school for over two years, and I spent many hours in the school hallways, in the front foyer of the school, and in after school program spaces, I developed strong relationships with teachers, administrators, and some students, many of whom were new to the United States. Over time, I developed a particularly close relationship with Ruby. She often sought me out in the hallway to get advice about situations in and out of school. For example, sometimes teachers and students did not recognize her British English terminology, which created frustrating situations for her in school (McKamey, 2011a). Ruby wondered how to respond to a modeling agency that promised her work if she paid a large sum of money for an initial photo shoot. She asked for help composing a speech for an after school event. In some cases, we problem-solved together while sitting in the hallway or in an empty classroom. In other cases, Ruby invited me to follow her to a class or an after school function to observe and later advise her about particular situations. 
In the years I was in the school, it also became common for teachers and administrators to pull me aside to talk about dilemmas, issues, or situations with which they were struggling. At first, I interpreted students and adults approaching me with situations and stories as calls to do something for them. "Doing something" about problems and situations gave me a sense of power and control, positioning me as a "savior" of students and teachers. This tendency highlighted my interpretations of the situation and precluded me from deeply understanding the ways students and teachers in the school made meaning of situations. This was particularly poignant because most students with whom I developed research relationships were ethnically and racially different from me and most had formative educational experiences outside the United States. Elsewhere, I have written about how over time I questioned and shifted my positioning of participants and myself (McKamey, 2012b, 2011b). For the purposes of this paper, it is important to note that over time, I assumed an attentive listening role that allowed participants to share their perspectives and provided me the opportunity to reflect on how my beliefs, identities, emotions, and experiences filtered what I could and could not "hear."

One theme that emerged as I listened to students, teachers, and administrators in the school was a frustration with negotiating and surviving within difficult situations stemming from top-down policies. For instance, the school had a rigid tardy policy. The principal locked the front doors 30 minutes after the first period bell to discourage tardiness. This policy did not accommodate students who had transportation issues, such as late buses or subway trains. It also did not account for students who were responsible for dropping their younger siblings off at elementary schools that started later than the high school, or for students who had doctor appointments. Because their appeals to the principal and central office did not change the policy, several teachers and students developed a texting system whereby late students could ask for someone to open a back door for them. The tardy policy, and other policies that obstructed students' access to school resources, encouraged people affected within the community to creatively find workable solutions. Within ISHS, finding individual and communal "workarounds" that gave students access to resources was as important to being successful in school as students' performing well academically. As we have seen in the stories about Ruby's schedule change, teachers and administrators can also struggle to find workarounds to manage successfully their responsibilities in school.

\section{Ruby’s Schedule Change: Five Perspectives}

From any one vantage point, when looking at an educational problem, it is easy to point a finger and say, "you are the problem," or "if only you did...." In the case of Ruby's schedule change, looking more closely at multiple perspectives illustrates how complex and multifaceted experiences and responses to an educational dilemma can be.

\section{Ruby: An Interpersonal Frame}

Ruby was a Nigerian student who has been in the United States for several years. Although Ruby spoke British English in her previous school in Nigeria and English was her primary language, she was often identified by her teachers as needing more support in learning English. Ruby's story is grounded in her personal experience and her 
interpersonal relationship with her teachers. Ruby frames her "problem," being scheduled out of Mr. Hansen's class, as an interpersonal issue between herself and Mr. Hansen. She says, "I like Mr. Hansen; I don't know why he changed me out of the classroom." At first, Ruby negotiates this situation by physically refusing to leave the class. When she does eventually change classrooms, she dismisses her new teacher as not being "real," waving his hands in the air like a magician and not a teacher. For Ruby, access to a classroom with a "real" and competent teacher is important to her success in school.

Ruby's focus on the interpersonal captures a particular view of the incident. It is interesting to note that although Ruby references the dozen or so students in the "crazy" class, she does not align herself with them nor does she reference that her classmates are all ELL learners.

\section{Mr. Smith: A Pedagogical Frame}

Mr. Smith was a student teacher in his early twenties, and I was Mr. Smith's university supervisor. Like many student teachers, Smith struggled with classroom management issues, especially in overcrowded classes with not enough desks to seat all of the students enrolled. For instance, students sitting in the front of the room were often engaged and interested in the lesson while the students crowded in the back of the room, some not even sitting at desks, were less engaged. When I talked with Mr. Smith in the faculty lunch area after the incident, he emphasized that he had advocated the schedule change because he was overwhelmed with the regular needs of a full class of students. He hoped the schedule change would provide ELL students with a smaller class size and better resources.

As a new teacher, Mr. Smith frames the "problem” as negotiating the pedagogical logistics of teaching too many students, many with diverse language learning needs, in a history classroom. Aligning himself with his mentor by using the pronoun "we," Mr. Smith says that he and his mentor do not have the pedagogical skills to serve adequately students with acute ELL needs. Mr. Smith's solution is pedagogical and structural: Transfer the neediest ELL students to a separate, specialized, smaller history class. Mr. Smith's solution provides him an opportunity to be successful as a teacher with a smaller group of more heterogeneous students. He also conveys a hope that the ELL students transferred into a smaller class would have access to a teacher with skills in teaching ELL students.

\section{Mr. Hansen: A Political Frame}

Mr. Hansen had been teaching in the school for almost ten years. Students frequently told me that Hansen was one of their favorite teachers, and when I observed him teach, I saw students engaged in complex projects and interesting discussions. Hanson made efforts to connect with students both in his classroom and in after school settings. He often stayed after school to tutor or mentor students, and was involved in a variety of after school student activities.

When I talked with Mr. Hansen in the hallway after the incident, he framed the issue as being related to his rights as a teacher. He said, "Filing a grievance is one way to 
"be heard" by the principal. Even if you don't like the way he handles the problem, he hears your problem; he has to respond to your problem.”

Mr. Hansen locates the "problem" as a political and structural issue: Too many students were assigned to his class. He seeks a "solution" through filing a union grievance that then forces the school administration to remove students from his class. His primary struggle is to have sustainable working conditions in his class. He aligns himself with other teachers who are not often "heard" by administrators in the building or central office. Hanson does not reference Ruby or the other ELL students who were transferred from class, nor does he reference pedagogical skills or knowledge needed to teach ELL learners.

\section{Mr. Medina: A Logistical Frame}

An immigrant to the United States himself, Mr. Medina was highly committed to serving students in his school, and especially English Language Learners. He often conveyed frustration with the limitations of available resources, especially the number of teachers and classroom spaces in the school. When I talked with Mr. Medina in his office about students' schedule changes, he sighed. "It's not an ideal situation. I don't have many options to place students." He talked about the less than ideal solutions he had to come up with at times, for instance, placing Algebra I students who were also ELL students into an Algebra II classroom because that was the only space he could find.

Mr. Medina frames the "problem" related to Ruby's schedule change as a logistical one-he was challenged with the impossible task of placing too many students in too few classrooms. This situation happened in part because of budget cuts that required the administration to fire teachers (mostly bilingual/ELL teachers). Medina's "solution" was to request new teachers and to request substitute teachers. For Medina, success is about managing and attending to the expectations and needs of staff and students. Medina's story references some specific students, but he does not reference their status as ELL learners.

\section{Conclusion and Questions Raised}

This paper details how a student, an administrator, and two teachers struggled to survive within difficult if not impossible working and learning conditions. In the stories provided here, each of the narrators framed the problem differently: as personal (Ruby), as pedagogical (Mr. Smith), as political (Hansen), and as structural/organizational (Medina). By assigning these positions to these narrators, I am not implying that these are the only positions/perspectives these participants held. These are selected narratives - snapshots in time-about how each of these participants made meaning of this situation. Through including multiple voices and interpretations, I invite you reader to consider other missing perspectives, such as the views of parents, of students who remained in the class, or other ELL students who were removed from the class. I also invite you the reader to consider people from your own experiences and contexts, who may resemble those included in this text (Barone, 2009).

There are also questions that arise but are unanswerable from this data. For example, why is it that ELL students, and not mainstream students, were chosen to move 
to the empty classroom? Why is it that ELL students were missing as a group from all but the student teacher's narrative? Why is it that the root cause of the incident, the state policy initiative, disappeared from all participants' stories?

As a researcher, I am aware that I am also narrating a story in this paper. In presenting layered stories about Ruby's schedule change, I am illustrating that there is not a single point or lever that could fix the "problem," because the "problem" is multifaceted with multiple dimensions at many different contextual levels, including interpersonal relationships, classroom pedagogy, school staffing and decision-making, district hiring and staffing, union rules, state level policy decisions, and the socio-national and inequitable ways that public schools are funded.

The current logic within educational policies and reforms assumes that mainstreaming ELL students in classrooms and improving teacher quality through strategies like increased professional development, firing incompetent teachers, and recruiting more "top academic performers" into teacher education will remedy the continued academic achievement gaps in United States schools. The stories I have collected in this paper about Ruby's schedule change were not about teacher competence - or the lack of teacher competence.

In each of the stories, the narrators struggled to survive and make good decisions within a resource poor context. For Ruby, success had less to do with her cognitive ability or English speaking ability, and had more to do with her ability to navigate and succeed within/despite a system that did not have enough resources to serve her needs. For the student teacher, success lay in negotiating a smaller class size and removing from his classroom the students who needed a teacher more qualified than he in teaching ELL students. For the teacher, success lay in using his working knowledge of the union and political system to decrease the numbers of students in his classroom to a size that was manageable. For the administrator, being successful meant managing scarce resources and distributing students and teachers across classrooms in a way that balanced teacher and student needs. None of these actions had to do with the content that is currently measured in standardized tests, and yet all of these actions were imperative to each of these people managing and being successful within their situations.

It would be easy to simplify the solution as, "The problem was that the school lacked teachers. This situation would not have happened if there were enough competent teachers in the school in the first place." Although the school would have definitely benefited from having more teachers, this generalized solution "flattens out" (AbuLaghod, 1993) the complexity of how different narrators experienced and strategized to negotiate this problem. The easy policy fix - to hire more teachers-does not account for studying, teaching, and surviving in a resource-poor school as it is lived and experienced by people within the school. The "hire more teachers" fix perpetuates the myth that schooling is only about learning academic standards and performing well on tests (or having students perform well on tests). It also denies the "lived curriculum" (Aoki, 1993) that encompasses a multitude of other complex tasks required to "succeed" in schools as students, educators, and administrators. Moreover, the "just hire more teachers" solution avoids raising larger questions about the inequitable distribution of resources within the school, state, nation, and globe (Davis \& Sumara, 2006). 
These multiple and overlapping accounts of how different people in different positions respond to contextual pressures within a public institution (Chase 2010), illustrate the complex ways people navigate, make meaning, and survive policy changes within an urban public school. They also illustrate how a policy decision proceeds in very ordinary ways, sometimes very silently, throughout the contexts and populations for which they were made (Barone, 2009). This work follows in the spirit of other narrative scholars like Binder (2011), Clandinin, Downey, and Huber (2009), Craig (2010), and Ritchie and Wilson (2000) who examine stories to understand the ways educators navigate within and across shifting educational landscapes and policies. Clandinin et al.(2009) write:

Teachers, caught in the squall as new policies are implemented and as landscapes are shifted by globalization, refugee populations, immigration, demographics, economic disparities, and environmental changes, find themselves trying to compose teaching lives that allow them to live with respect and dignity in relation with children, youth, and families. (p. 145)

These layered stories provide a slightly wider lens to capture the ways multiple agents-a teacher, a teacher educator, a student, an administrator, and a researcher-navigate an educational "squall."

Earlier in this paper, I wrote about my urge to "do something" in response to hearing stories in schools. In my development as an educational researcher, I learned to step back and listen carefully to stories. Similar to talk therapy (Mann-Feder, 2011), I believe that many times, my listening to a story or situation told out loud elicited the teller to name ways that they could navigate and find solutions to an issue or problem.

This listening is no small matter, and many people in urban schools do a lot of important talking, listening, problem solving, and creative workarounds. Sometimes these workarounds are individual, as in Ruby's schedule change situation. Sometimes these workarounds are collective as in the back door texting solution. It is important to recognize and value the additional work that teachers and students within urban schools manage on a daily, sometimes minute-to-minute basis.

It is also imperative that we continue discussing how and in what situations students and educators share how they manage tensions in schools in ways that permit thinking across individual dilemmas and systematic constraints (Britzman, 2003). This "transdisciplinary" charting project (Davis \& Sumara, 2006, p. 3) would recognize differently positioned experiences towards building collective and synergistic understanding, support, and action. In this frame, "success" is not an individual accomplishment or grade on a test, but resides within and among community members as they talk with one another about overcoming obstacles (Norton \& Toohey, 2011) and in imagining new possibilities and creative productions (Davis \& Sumara, 2006; de los Reyes \& Gozemba, 2001; Weiss \& Fine, 2000). The reader's theater and analysis of multiple stories is the beginning of one type of "charting." 


\section{Afterward: Ruby's Schedule Change: A Reader's Theatre}

As a graduate and undergraduate teacher educator, I would like to produce texts that are useful not just for researchers, but also for educators, teachers, and policy makers. I invite educators to utilize the introductory text as a reader's theater with their students to promote dialogue about the perspectives portrayed in the text. 


\section{References}

Abu-Laghod, L. (1993). Writing women's worlds: Bedouin stories. Berkley, CA: University of California Press.

Aoki, T. (1993). Legitimating lived curriculum: Towards a curricular landscape of multiplicity. Journal of Curriculum and Supervision, 8(3), 255-268.

Barone, T. (2009). Comments on Coulter and Smith: Narrative researchers as witnesses of injustice and agents of social change? Educational Researcher, 38(8), 591-597.

Binder, M. (2011). Remembering why: The role of story in educational research. in education, $17(2)$.

Britzman, D. P. (2003). Practice makes practice: A critical study of learning to teach. Albany, NY: State University of New York.

Cadiero-Kaplan, K., \& Rodríguez, J. L. (2008). The preparation of highly qualified teachers for English language learners: Educational responsiveness for unmet needs. Equity \& Excellence in Education, 41(3), 372-387.

Chase, S.E. (2010). Narrative inquiry: Multiple lenses, approaches, voices. In W. Luttrell (Ed.), Qualitative educational research: Readings in reflexive methodology and transformative practice. (pp. 208-236). New York, NY: Routledge.

Clandinin, D. J., Murphy, M. S., Huber, J., \& Orr, A. M. (2010). Negotiating narrative inquiries: Living in a tension-filled midst. The Journal of Educational Research, 103(2), 81-90.

Clandinin, D. J., Downey, C. A., \& Huber, J. (2009). Attending to changing landscapes: Shaping the interwoven identities of teachers and teacher educators. Asia-Pacific Journal of Teacher Education, 37(2), 141-154.

Craig, C. J. (2010). Research on the boundaries: Narrative inquiry in the midst of organized school reform. The Journal of Educational Research, 103(2), 123-136.

Counternormativity Discourse Group (2005). Performing an archive of feeling: Experiences of normalizing structures in teaching and teacher education. Journal of Curriculum and Pedagogy, 2(2), 173-214.

Davis, B., \& Sumara, D. (2006). Complexity and education: Inquiries into learning, teaching and research. New York, NY: Routledge.

de los Reyes, E., \& Gozemba, P. A. (2001). Pockets of hope: How students and teachers change the world. Westport CT: Praeger Publishers.

Donmoyer, R., \& Yennie-Donmoyer, J. (1995). Data as drama: Reflections on the use of reader's theater as a mode of qualitative data display. Qualitative Inquiry, 1(4), 402-429. 
Donmoyer, R., \& Yennie-Donmoyer, J. (1998). Reader's theater and educational research-give me a for instance: A commentary on Womentalkin'. International Journal of Qualitative Studies in Education (QSE), 11(3), 397-407.

Ely, M. (2005). In-forming re-presentations. In Clandenin, D. J. (Ed.), Handbook of narrative inquiry: Mapping a methodology (pp. 567-598). Thousand Oaks CA: Sage Publications.

Iddings, A., Combs, M., \& Moll, L. (2012). In the arid zone: Drying out educational resources for English language learners through policy and practice. Urban Education, 47(2), 495-514.

Karp, F., \& Uriarte, M. (2010). Educational outcomes of learners in Massachusetts: A focus on Latino/a students. Gastón Institute Publications, Paper 159. Retrieved from http://scholarworks.umb.edu/gaston_pubs/159/

Luttrell, W., Ward, J., \& Holland, J. C. (2006). “Nice kids”: The N-word and signs of respect: Culturally relevant knowledge of urban youth. In M.G. Constantine \& D.W. Sue (Eds.), Addressing racism: Facilitating cultural competence in mental health and educational settings (pp. 145-159). San Francisco, CA: Wiley.

Lyons, N. (2007). Narrative Inquiry: What possible future influence on policy or practice? In D. J. Clandinin (Ed.), Handbook of narrative inquiry: Mapping a methodology (pp. 600-631). Thousand Oaks, CA: Sage Publications.

Mann-Feder, V. R. (2011). Child and youth care work and talk therapy. Relational Child \& Youth Care Practice, 24(1/2), 67-71.

McKamey, C. (2006). You've gotta make Washington high like you: Cultures of caring in a Boston high school (Unpublished doctoral dissertation). Harvard Graduate School of Education, Cambridge, MA.

McKamey, C. (2011a). Restorying “Caring” in education: Students' narratives of caring for and about. Narrative Works: Issues, Investigations, \& Interventions, 1(1), 7894.

McKamey, C. (2011b). Uncovering and managing unconscious ways of 'looking': A case study of researching educational care. Psychodynamic Practice, 17(4), 403-417.

Mischler, E. (1995). Storylines: Craftartists' narratives of identity. Cambridge, MA: Harvard University Press.

Norton, B., \& Toohey, K. (2011). Identity, language learning, and social change. Language Teaching, 44(4), 412-446.

Quinn, N. (2005). Finding culture in talk: A collection of methods. New York: Palgrave.

Ritchie, J. S., \& Wilson, D. E. (2000). Teacher narrative as critical inquiry: Rewriting the script. New York: Teachers College. 
Squire, C. (2008). Experience-centered and culturally-oriented approaches to narrative. In M. Andrews, C. Squire, \& M. Tamboukou (Eds.), Doing narrative research (pp. 41-63). Thousand Oaks, CA: Sage.

Tsai, M.-L. (2007). Understanding young children's personal narratives: What have I learned from young children's sharing time narratives in a Taiwanese kindergarten classroom. In D. J. Clandinin (Ed.), Handbook of narrative inquiry: Mapping a methodology (pp. 461-488). Thousand Oaks, CA: Sage.

Weiss, L., \& Fine, M. (2000). Construction sites: Excavating race, class and gender among urban youth. New York: Teachers College Press. 